\section{Briginal allrticlę.}

A STUIY OF 'TWENTY-FOUR CASES OF 'TYPHOID FIVVER WITII SYMP'TOMS OF PEIRI'IONEAL INFEC'IION; LAPARO'TOMY.'

Summary.-Sieventeen Cases of perroration of Intestine; 'Two Casies of Preperforative Nicrotric arkas; Onk Case of Rup'rulrki) Mrshe tremic Gland ; 'Threk Casks Cause of Symptoms UNDETHRMINED, DIAGNOSIS NOT CONHIRMIED.

Grovping and Analybis of Casles;

Grenkal Conchusions; Detaingd Repor't of Casks.

REIOR'LEI) HY (HEORTE B, SHATTUCK, M.D., J. COLLANA WARRLN, At.1)., FAlRLAR (OLIH, M.J),

Committee of the Boston Society for Medical Improvement.

'Ius whole number of cases studied by this Committee is 27 , all coming, in the years between 1895 and 1900 ; 9 cases from the Massuchusetts (ieneral Ilospital; 1 (i cases from the Boston City Ilospital; 1 case from St. Elizabeth's Hospital, and 1 case from the Boston C'hildren's Hospital.

In the year 1895 there are 3 cases, but only one of them will bear analysis as a cise of gennine typhoid fever; 1 case in 1896,4 cases in 1897,5 cases in 1898 , and 14 cases in 1899 .

'This is a striking illustration of the incrense in the oporative tendency. 'The data from which this analytjeal report has been made are the complete medical, surgical and post-mortem records of the several hospitals, togrether with the summarized statements and opinions sent in by the physicians and surgeons in attendance. From this available material a concise view of each case has been mate with reference to all the important points bealling in any way on the diagnosis and treatment of peritoneal infection in typhoid fever.

'The Committee would deprecate its eritical comments of to-rlay being interpreted as fault-finding with the practice of earlier years ; neither rloes the Committee forget that the idleal is not always, or under all conditions, to be realized in practice. Doubtless a nearer approach to the ideal should be aimed at amil would now be possible than is fomm in most of the cases here reported. $\Lambda$ ud the (ommittee is still further quite aware that the irleal itself - for example, in regard to such a matter as the value and application of the white blood count - is subject to further changes; the value of pain as a warning symptom also merits further study.

Of the 27 cases $\Lambda, 13$ and $C$ must be thrown out of our consideration, becanse of no proof that they were genuine cases of typhoirl. C'ases 13 and $C$ were both cases of alvanced general peritonitis when first seen, and in both of them there was no proof that typhoid was the origin of the peritonitis.

Case $\Lambda$ was brought to the City Ilospital in a morihund condition, and showed greneral peritonitis at the operation. C'ultures from the interior of the gallblarder showed the presence of the bacillus typhosus. 'This, however, camnot be accepted as conclusive proof that the case was one of typhoid peritonitis. Cultures from the peritoneal fluid showed only the staphylococcus allous. It is an accepted fact that typhoid bacilli can and do remain active in the gall-bladler for

1 Report presonted it a meoting of tho lBoston Soolety for Medical Improveruent, A pril 16, 1900. montlss and gears after an attack of typhoid lever. For example, Miller ${ }^{2}$ has reported a case in which the bacillus typhosus was found in the gall-bladder seven years after an attack of typhoid fever. There is no proof, therefore, that the peritonitis in Calse $\Lambda$ might not have been of other origrin than typhoid fever, aml, therefore, it camot be inchuded in our list of cases for study. This series, then, embraces 24 cases, which are all moleniable cases of typhoid ; there can be no controversy on this point.

Wighteen cases had a positive Widal serum reaction in acldition to the evidenes furnished by the elinical course of the oase and the positive pathological evidence furnished by the operation or post-mortem exmination. In 3 cases tho Widal test was not marle; in 3 cases the Wirlal test was menative. 'Two of the eases in which it was not malle ocemreel in the years 1895 and 1896 , a period of time before the use of the test.

Of the $f$ eases in which the Widal test was not, made or was negative there can be no doubt of the diagnosis of typhoid, because of the findings at the operation or the post-mortem which fully corrolorated the elinical diagnosis. In 2 of the cases in which the Widal test was not makle the dia\%o test was positive.

All of the 24 cases hal symptoms upon which a diagnosis of intestinal perforation was made and for which an operation was performed.

'Three of the casess (XXII, XXIII and XXIV) presented symptoms strongly suggestive of intriablominal infection, and aceordingly were operated "1pon with a diagnosis of intestinal perforation, lut at the operation no positive cause for the symptoms was found. 'Two cases recovered from this exploratory operation, and 1 died. 'These cases are of the eqreatest importance from the diannostic point of view, and will be considered carefully when the subject of "Symptoms and Diagnosis" is taken up.

Ciase XIX hal chanacteristic symptoms of acute sudken peritoneal infection, and operation discovered a gemeral septic peritonitis, hut dial not determine the cause; therefore this ease should not be classed with those in which the couse of the peritonitis is certain, although it certainly seems rational, on consirlering the history and the symptoms and the fact that several different thin places in the intestinal wall were fomm at operation, to consider it a case of perforation.

In Cases II and XVI the classic severe symptoms of perforation were simulated, but operation discovered the eatuse of the symptoms to be a general septic peritonitis originating in damaged and necrosed areas of peritoneum over the bases of one or more typhoid ulcers. 'These cases might be called eases of progressive peritoneal infection from threatened perforation.

In Case XXI the symptoms amply justified the diagnosis of intestinal perforation, but operation prover that the symptoms, which were identical with the usually accepten symptoms of perforation of the bowel, were due to a general septic peritonitis arising from a ruptured mesenteric glind.

So that out of the 24 cases of tiue typhoid only 17 were cases of peritoneal infection from actual perforation of the intestinal wall. 'Two cases were of general infection from threatened perforations or areas of necrotic peritomeum; 1 ease of general infection from

\footnotetext{
2 Johns Hopkins Hospital Bullotin, May, 1898.
} 
a ruptured mescenteric gland; 1 ease of gencial infection from an unknown canse, presumably intestinal perforation; 3 cases had no erertain cause for the symptoms which demaniled operative interference.

Since it will be shown that in many cases no differentiation between the usually accepted symptoms of actual perforation and the symptoms of general septic peritonitis can be malle, this series of 24 cases grives us, for further study, 21 cases of grave peritoneal infection in typhoid fever and 3 cases of mistaken diagruesis, but with symptoms of peritoneal infection.

Diagnostically and from the point of view of treatment all of these cases should go in under the head of acute peritoneal infection in the course of typhoid fever. It may be well, however, to analyo the two groups of cases separately, dividing the perforations firom the other cases.

()f the 24 cases presenting acute abrominal symptoms, with or without discoverable cause, 18 were males and o were females. () the 18 males 15 were under thirty yoars; 1 was forty-five years; 1 wass thirty-eight years ; 1 was thirty-two youls ; 14 cases were between the years of nineteen and thirty and 1 case was sixteen years. () the females, 6 in number, 4 were between twenty and twenty-six years, 1 was forty years and 1 was sixteen years.

The total number of casces shows, therefore, that acute abrominal infection occurs most often in young alults between the ages of eighteen and thirty years; that it is most frequent in men; that it is rase in elililren. It is noteworthy that 2 of the cases presenting acute abdominal symptoms without discoverable cause occurred in young women, aged twenty and sixteen years, respectively.

These facts in regard to age and sex are in grenoral accorrl with the investigations of J)r. 1R. 11. Fitz and others, although the pereentage of those under thirty years of ange happens to be somewhat larger thin in 1)r. Fitz's tables."

$\Lambda s$ to the question of typhoid perforation in children under twelve years of age, we have been able to find but 4 cases of operation for perforation in children under that age in all the cases reported in literature.

Cushing: ${ }^{1}$ Boy, nine years old, on which case 3 laparotomies were done; the case recovered. 'Three cases are given in Keen's ${ }^{5}$ talles of cases of operation for typhoid perforation.

All the cases but one were white in color. 'This proportion of blacks to whites would very likely loe different in other parts of the country, where the proportion of the colored population to the white is greater.

In 18 of the 24 cases the elinical nature and course of the typhoid was mild, and in 15) of these 18 mild cases perforation or general septic peritonitis was present. 'The 3 cisses which presented symptoms without certain cause: were mild cases.

Onc case, XVII, was a "walking typhoid"; 6 cases, II, VI, VIII, XII, XIV and XX, wore severely sick typhoids. All of these 6 cases had general septic peritonitis from actual or threatened perforation, and all died.

'These facts are in accord with the hitherto accepted knowledge that intestinal perforation in typlooid fre-

s Irrusactions of the Associntion of Amerioan Physioing, vol. vi, p. 200.

. Jolung Jopkins Hospltal Bulletin, 1898.

- Surgical (Jomplichtiong and Seruels of 'Typlioid Fovor. quently occurs in those cases of a mild type, or, in other words, there is no relation between the severity of the comrse of the fever and the likelilioorl of intestinal perforation.

The ditliculty of the diagnosis of the peritoneal infection in cases of the severe type will be touched upon later.

The sudden fulminating symptoms in the severely sick cases will be found in the miajority of instances to he: due to a general septic peritonitis, which was often unsuspected and had slowly progressed. (On the other hamd, a sudden, acute onset in the mild type more often meant sulden intestinal perforation with extravasation. In certain of the severely sick cases in this series it would seem as if a diagnosis of the onset of tho peritoneal infection was practically impossible.

'The organic complications were very few : 'Three cases had mitral regurgitation amply compensated ; 1 casse in which operation discovered no cause for the symptoms had an especially feeble heart, with mitral regurgitation, yot this case recovered from the exploration; in ! cases intestinal hemorrhages are noted; in 2 cases it occurred three weeks before the severe symptoms of perforation appeared; in 2 cases it occurred forty-eight hours before the severe abdominal symptoms, but there: was a distinctly comfortable period between the occurrence of these hemorrhages and the sudden onset of abdominal pain. In 3 cases intestimal hemorrhages preceded and coincided with the beginning of peritoneal infection. Case XIX had daily intestinal hemorrhages for three days before sudden aloilominal symptoms. Case XII had a severe loemorrhage five days before the symptoms for which operation was done; but this case was so sick and stupid as to justify the supposition that perforation probably took place long before the foul and evidently long-established general peritonitis was diagnosed. Case: VI had two sevore hemorrhages just preceding and coincident with the perforation. In 2 cases intestinal hemorrhages are noted after the operation. In Case I a severe hemorrhage five days after the operation was undoubtedly the cause of death.

Intestinal hemorrhage, inasmuch as it must como through extensive ulcerition of the intestinal wall, and since this may mean proximity to the peritoneal coat of the intestine, must be to a large extent a dasiger signal of perforation. The occurrence of intestinal hemorrhaures, therefore, should properly demand a close watch for the symptoms of begrinning peritoneal infection, frecuent examination of the abdomen to detect tenderness or abnormal rigidity and muscular spasm, associated with frequent lencocyte counts. The occurrence of acute abdominal pain following and coincident with intestinal hemorrhage should lead to the suspicion of peritoneal infection.

\section{THIS WELK IN TIIE MISEASE IN WIICII PJEITONEA} INFBCION TOOK PיACE.

Of the cases in which perforation and general peritonitis existed the acute ablominal symptoms appeared at the following times: In in cases at the end of the second or first of the third week ; 8 cases at the end of the third week; 1 cense during the fourth week ; 4 . cases during the fifth week; 1 case during the sixth week; 1 case during the ninth week; 1 case during tho: eleventh weok in a relajese.

Of the cases operated upon under a mistaken diag- 
nosis 1 was in the fourth week, 1 in the fifth week and 1 in the sixth week. 'The diagnostic symptoms of intestinal perforation in typhoid as they ane usually Imilerstood, namely, sulden abolominal pain, fall of temperature, collapese, genceral abdominal rigidity and tenderness, with or without vomiting, anxious facies, coming on without warning, do not present themselves as a complete pieture in any one of this series of cases. The majority of the cases show records of definite warning symptoms, or, in other words, pressent evidences of a grialual onset of peritoneal infec:tion.

It is, in fact, rational to conclude from a study of the symptoms in these cases, togrether with the finclings at operation, that the severe symptoms corresponding to the ordinary text-book picture of intestinal perforation in typhoid were, in the majority of casces, caused by the greneral septic peritonitis resulting from a perforation or a threatened perforation, the oceurence of which (the perforation or local area of infection) was indicated more or less plainly by symptoms of less severity, which antedated the severe or so-called diagnostic symptoms by a definite number of hours.

If it is one thing to operate for intestinal perforintion, and a decidedly different thing to operate for a septic peritonitis resulting from a perforation, the fact should be thoroughly understood that the severe and usual diagnostic symptoms in this class of cases meant that septic peritonitis had already existed for some time, and that the perforation took place at a previous time and was evidenced by milder and more? localized symptoms. It is a fact that in the majority of these cases definite premonitory symptoms are recorded at a time: more or less remote from the severe symptoms which first leal to the diagnosis, and for which the physician called the surgeon in consultation.

Seven cases of the 21 in which operation found canse for the symptoms, namely, I to VII, inclusive, presented a sudden, acute picture of grave abdominal infection without any premonitory symptoms. ()f these 7 cases 5 (I, III,IV, V and VII) were mild typhoids, whose general and mental condition was favorable to the noting of abdominal pain. 'T'wo casess (II and VI) were very sick, stupid and semi-conscious ; a class of cases in which the occurrence of considerable localized abdominal pain might not be noted. In Case II the symptoms, suclden though they were, were due to a general peritonitis from the damaged peritoneum over the base of one or more ulcers, and not due to a sudden perforation. In Case VI the sudden symptoms were caused by the presence of a general peritonitis which had extended from a localized abseess originating from the intestinal perforation which at its appearance had given no symptoms, so that of the 7 cases which presented fulminating symp)toms and which most elosely conformed to the hithorto established idea of tho symptoms of intestinal perforation only 5 proved to be due to actual sudden perforation, while $I$ was not a case of perforation at all, and in the other the perforation and progress of the localimed peritonitis with aloseess formation did not cause any symptoms.

The sudken onset in these 7 cases presents a dificrent picture in the 5 cases in which the symptoms were proved to be due to actual perforation. In these cases we have the symptoms of sudden severe pain coming on without warning, more or less localized in the right iliac region, accompanted by localized muscle spasm and tenferness, with the valying amount of shoek. In the 2 anses in which the symptoms were: due to general peritonitis, we have a pieture suggresting general peritonitis, malked collapese, great, distention, and general tenderness and rigidity. It might be conchuded from a study of these 7 cases that in mild typhoids the appearimee of sulden severe ablominal symptoms without any previous abdominal pain or tenderness may most of ten moan sudilen intestinal perforation with extravasation into the general peritoneal cavity, and that the symptoms inily vary, the chief symptoms being sudklen pain, temilerness and muscular spasin localized, attended with more or less markerl shook; but in very sick and lethargic: cases the appearance of severe abrominal symptoms without warning most often means the presence of geenemal septic peritonitis originating in some one of the possible sourees of peritonitis in typhoid, the cradual onset of which it has been improssible to dingnose becanse of the sick and stupid condition of the paitient. It has been stated that in the above 7 cases there were no warning symptoms. By this is meant direct abdominal symptoms - pain, tenderness and musculan spasm. It shomld be stated, for the sake of completeness, that 3 cases had one or more intestinal hemorrhages on the two days preceding the acute abdominal symptoms. (One case had several ham chills without hemorrhage during the twenty-four hours precenling the onset of the peritoneal symptoms. The oceurrence of ehills as a symptom of peritoneal infection in typhoid is probably rare. It cim only be a symptom lealing to suspicion of infection when it is un associated with hemorrhage.

J. F. R. Gairdner" states that rigor as an initial symptom of peritoncal infection in typhoid is uncommon. He noted it in only 2 cinses out of 4.7 studieal by him. It is noteworthy that in 1 of his cases ancl in the case of Jemner the peritonitis ushered in by rigors was due to the rupture of a softened mesenterie grland. In Case XXI, the only case of our series of peritonitis from the sime callse, no ehill occurred. In the absence of intestinal hemorrhage to account for rigors it might not he irrational to suppose that it might occasionally be present in the early stages of peritoneal infection.

In those 3 cases in which no canse for the symptoms was found at operation the onset of the same was gradual. 'These cases will be referred to again in the subject headed "Symptoms and Diaunosis."

We have 14 cases, namely, Cases VIII to XXI, inclusive, with more or less gradual onset of the abdominal symptoms. Eleven of these are cises of intestinal perforation and resultant general septic peritonitis; 2 are cases of general peritonitis without perforation; 1 a cesse of general septic peritonitis of unknown origin, though probably due to a perforation. One of the perforative cisses (Case XVII) was a "walking typhoid," and had probably hat greneral peritonitis for at least thirty-six hours before chtering the Massachusetts (ieneral Hospital.

In all of these 14 cases distinct warning symptoms antedated equally cistinct severe and diagnostic symptoms. 'The miliker symptoms, which we must conchule marked the begimning of the peritoneal infection, were chiefly various degrees of abdominal pain and - Glasgow Modionl Jouranl, 1897, vol. xlvil, p. 103. 
temblerness, cither lomalized or general, complatimed of by the patient. 411 of these 14 cases wore mild types except 4. In only I of the 14 catses wats any complaint recomded of alolominal pain until the complaint chshering in the severe symptoms, and in the single: exeeption to this the complaint of ablominal pain antedated the antual perforation hy some weeks.

In 1 cases ahdominal distention throughout the course of the fevelp is noted. In ? cases there is no pecord of any alulominal complaint or almormality until the peritoneal infection was under way. In every ond of these casess recorded compleint by the potient of abdominal pain was followed by poritoneal infection. 'The severe symptoms followerl these warning symptoms at various iutervals in every case, and there can be little doulst that the severes symptoms, when they appeared, meant that the peritoncal infection haul become genceral and alaming.

$\Lambda_{11}$ allialy'sis of these premonitory symptoms shows that in (f cases the pain complained of was greneral alnlominal pain; in 3 cases localized in the left iliac: regron; in 1 cotses in the right iliac region; in 1 catse in the lower ablomen; in 1 case general abdominal pain, and also pain in the rectum and hladder; in 1 ease the pain begin in the epigastrium and later becams: marked in the right iliac region. It is much to be regredted that the importatuce of this abdominal pain was apparently not appreciated, as slown by the cisse records.

In :3 cases romperatively complete physical cxamination is recorded as marle at the time. In no case was there a record of as carceful an examination of the patient in every detail as the importance of the symptoms clemanderi, so that our knowledge of the aceompinying comlitions of tenderness, muscular spasm, lencocylosis, pulse ind tomponenture: is insullicient.

In 2 cases the complaint of pain was preceded by vomiting. In only 2 cases wis the recomd of a leucocyte comit mode, and in these cases it appear's that the blood count was only done once. $\Lambda$ s will be shown moler the houl of "Leacocytosis as a Nymptom," an isolated bloorl comot is of littlo or no valuc. In 1 casse genceral abdominal tenderness and rigidity wore noted, and in 2 cases there was general tenderness. In 4 catses there is no record of any physical examination, lut a record that morphine was given. In 3 cases it is noted that the pulse and temperature were rising. This warning ablominal pain preceded the severe symptoms by hours and days; it appeared in 1 case sixty hours before; 1 case forty-eiglit hours before ; 1 atse twenty-four hours before (Case XVII); 4 asess twolve to fifteen hours before; 4 casses eight hours lofore; 8 cases three to five lour's before. It is noteworthy that the 2 cases in which no actual perforation but general peritonitis from other eauses existed had equally marked advanced pain.

Cases XVI and XXI, where the severe symptoms followed just as in the cases of perforation, point plainly to the reasoning that the early pain in these cases was due to local peritoneal infection, and that the severe symptoms were due to the establishment of a general infection.

'The severe abdominal symptoms in every case rletermined the diagnosis and the decision to operate. In general these symptoms were those of general septic peritonitis, namely, general alolominal pain, severe; general tenderness and rigidity, with distention, colJapse, poor pulse and anxious facies.
In only 3 of the cases was there any vomiting. Tlae chassical sudden fall of temperature is not present in many of the catses. The tempremature fell somewhat in a fow casces. In 2 casess it fell to normal, and begall at onee to rise; in 1 ease it foll to and remained sulnormal; in 3 atses a slight drop of temperature is noted; in 6 ases there was no fall of temperature, and in :3 rasess it is recorded as rising.

In 8 casces a lencocyte connt wits taken at at time corresponding to these severe symptoms; in 1 cases it showed lencocytosis; in 4 ciseses it showed no lencoocytosis. 'The leucocyte counts are, however, of only relative value, as will be comsidereal later moler the loealing of " Ietucocytosis as a Symptom."

In only 2 casces iwats a record of obliterated liver duluess maile.

'Tlue constant symptoms in every case are ablominal pain, gencral tenclerness and rigillity, with clistention, associated with collapese and rapid, fectble pulse.

$\Lambda$ comporison of the severe aldeminal symptoms in the two dasses of casess - the 7 casces where warning symptoms were not present and the 11 cases with warning symptoms - shows distimet differences in tho severe symptoms in those in which the sudlen intestimal porforation and extravasation came on without warning. $\Lambda$ s has been stated, the severe pain, more or less localized, with shock and muscular splatsm and tendermess, chatratererized the first set of easest, and the shook varied in the different cases. In 1 cesse the pulso was notover 100 . There was no vomiting, no general abdominal tenderness or righidity, and no dis tention in any cise.

Contrasted with this first set of cases, the severe symptoms in the second set present a much erraver pieture. It is noteworthy that in the: 2 ases in thes lirst set, in which general peritonitis was the catuse of the symptoms and not intestimal perforation, the pieture corresponds to the severe pieture in the second class of cases.

It should be noterl that if the signs of actual perforation with extravasation are local to a great extent, as in the 5) cases of our first set, a careful examination of all casses at the warning complatut of pain might in many of them grive us definite diannostic signs, as in Ciase III, for example.

$\Lambda$ comparison of these two sets of cases - the 7 with sulden symptoms without perforition and the 1.1 catses with severe symptoms following prenonitory pain - bears out the point that in most of them no positive diangosis of perforation was male, but only at cliannosis of the genedal peritonitis resulting from the jerforation.

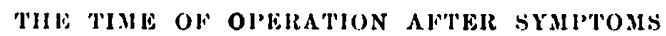 AI'I'LARIID.}

In the 7 cases with no warning symptoms operation was done within twelvo hours in every case; 1 case within an hour and a half ; 3 cases within four hours; 1 case within seven hours; 1 case within eight hours; 1 case within twelve hour's.

$\Lambda$ the operation general septic peritonitis was not evident to the eye in Cases I, III and VII. In Case $\mathrm{V}$ it is noted as just boginning and not far advanced. In Case IV the perforation was protected by weak alliesions, and no general infection had taken place up to the date of operation. In Cases II and VI general peritonitis was farther advaneed and was evidently the cuuse of the sudden symptoms, so that only 5 
operations can be said to have been for perforation itself and not for general peritonitis; and of these 5 casses 2 cases, namely, Cases I and IV, may be said to have recovered from the operation, although Case I dicel at the end of five days from excessive intestinal hemorrlatere. ()f the 14 eases which hat warning symptoms ? were operated upon within five hours from the severes symptoms, or from the time of positive diaguosis of perfuration; 1 cease within oight hours; 1 case within nine hours; 3 cases within twenty-four hours; 3 casses, however, were not operated upon for twenty-four hours alter general peritonitis was plainly evident.

Reference to the annexed table will show that the average time of the operation alter the early warning symptoms was twenty-three hours.

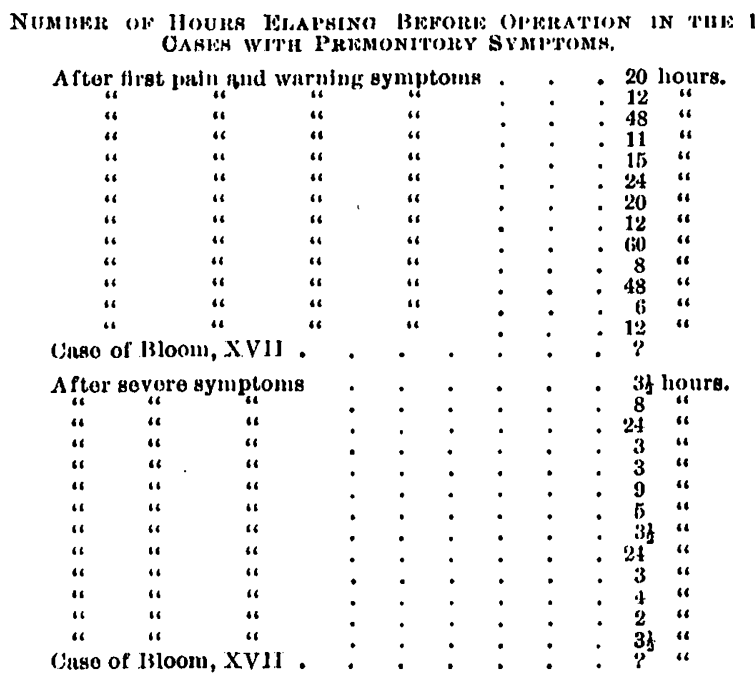

If it is granted that the early pain, ete., meant perforation of beginning peritoneal infection, and the severe symptoms meant general septic peritonitis, then it must be granted that operation took place from six to sixty hour's after it was first indicated.

Ii :all of these 14 cases the operation should be considered as primarily direded against the septic peritonitis and not the intestinal perforation. 'The recoveriess from the operations in this elass of cases are Cases XVI and XVII. ('ase IX is reported to have recovered from the operation for one perforation and to have lived eight days, until a second perforation necessitated a second operation, followed by death. It has been seen in the analytical report of this case that such a view of it eamnot be premitted. It seems just to decide that this case did well alter the first opeeration, Intil the extensive necrotic changes in the eecum involved the first sutured area amb caused griving way of the sutures and a second extravasation.

SITUATION OF THE PRRFORATION ANI SITUATION OF THE DAMAGED AREAS.

We have in this series of cases 17 cases of true intestinal perforation and 2 eases of threatened perforation, with damaged and necrosed peritonoum. In every case the perforation or impending perforation was in the ileum.

In 7 cases it was within one foot of the cecum; in 1 cases it is noted as close to the cecum; in 1 case two feet from the cecum; in 1 case three feet from the cecum ; in I case four feet from the eecum ; in 5) cases the site is not recorled; in 3 cases it is recorded to have becn the size of a "pin's heal"; in 2 cases the "size of a dime"; in 1 case the size of a " split pea" ; iil 1 case to have been a large, irregular hole: in 1 case two perforations close together, near the cecum. In only 1 case (Case XV) was a second perforation found at the post-mortem.

In Case XIV the perforated coil of intestine was foumd situated low down in the pelvis, and in this case the initial pain complatined of was referred to the regrion of the rectum and the blathler.

'The method of elesure of the perforation in every case but one consisted of inversion of the hole with silk sutures. In 1 ease (Case XI) the ulcer was resected by a $V$-shapued incision. In ('ase $X$ two rows of silk lembert sutures were used, eausing extreme inversion of the intestinal wall. 'This case died within thirty-six hours, with extreme aldominal distention and obstinate vomiting. At the antopsy it was found that the use of the two rows of sutures had reduced the lumen of the intestine to such an extent that it only took the top of the little finger, and that it was obstrueted by a moderate amomint of hald fecal matter. It seems legitimate to raise a query as to whether this case died from peritoneal infection or from intestinal obstruction, from the great inversion of the wall of the gut.

In 3 cases, in addition to suturing perforations or threatened perforations, alditional suspicious thin places in the intestinal wall were inverted. This procedure, provided the condition of the patient justifies the expenditure of the extra time, is certainly advisable in all operations for typhoid porforation. It has been alvocated by Sifton ${ }^{7}$ and also by 1 lill in a cise reported by Koen. ${ }^{8}$

In 7 eases out of the 21 the abdominal incision was median ; in 2 casses the incision is not recorded; in 12 cases the primary incision was in the right iliac regrion. In only 2 cases are counter openings for irrigation and drains noted. 'The right iliac incision proved most cappable of allowing speedy aceess to the infecting lesion. In 2 of the cases where the median incision was used it is especially recorded that long overhauling of the intestines was needed before the perforation was found. In 1 of the cases in which the median incision was used the time of operation is recorded as one and a half hours. Certainly the site of the infected areas in this series of casses points to the routine employmont of a right lateral incision.

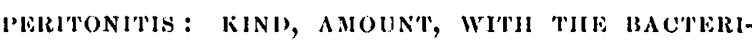
(O)OCICAL, FINIINGS.

Unfortumately, the value of this series of cases is much impaired by the lack of hacteriolegioal datar concerning the nature of the general infection. If this series of cases furnished eomplete records of a careful physical examination at the appearance of the first symptoms in every case, alld also complete bateteriological evielence concerning the virulence of the peritonitis resulting from the initial infection, we should be much better equiped to arrive at some definite statistical basis for establishing an approximate prognosis in such cases.

'I'hree cases, namely, Cases I, III and VII, operated on one and a hall, three and eight hours after the sudden onset of the perforation, land no visible

7 Chicago Clintenl Roview, vol. iv, p. 368.

s Surgieal Complications and Sequels of 'yphoill Fovor. 
macroscopical signs of general peritonitis. Calse I lived noally a week, and ilied from intestinal hemorrhace, and the autopsy showed no general peritonitis. Cases III and VII both died within sixty hours, one with the symptoms of general peritonitis ancl the other without such symptoms. There were, however, no bacteriological studies of the peritoneal infection in these: 3 cases at the time of operation. 'Iwo of the cases may very probably have died from a virulent infection, which did not cause any visible signs.

Vincent "experimentally has called attention to the fact that a streptococeus peritoncal infection in typhoid is usually a fatal complication. Vincent's studies have been corroborated by Flexuer and Frankel.10 ('ushing ${ }^{11}$ reports a case in which operation was done within an hour or two after perforation, and at the operation no visible signs of general peritonitis were present. C'ultures and cover-slip preparations from the feeal fluid pouring ont of the perforation in the intestinal wall showed larege quantities of streptococei, and the case died of streptococens peritonitis.

It is perfectly within reasomalibe bomels to believe that one or more of the supposedly favomable cases in our scepies may have hall a streptococeus infection. Certainly we have no evidence to the contrary.

Cases 11 and V show a begiming general peritonitis, as evillenced by gats and serous fluid free in the ablominal cavity, but indieated no injection of the peritoneal cont of the intestines. Both of these cases, so far as the macroscopical appearance went, seemeal finvoralsle, yet botlı died. Ciultures taken in ('ase V showerl a pure infection of the lacillus typhosus.

('ase IV had no genemal peritonitis, as has been stated. Case XVI was one of gencral peritonitis arising from the same cause as in (ase: 11, llamely, damaged peritoneum; yet in ('ase XVI peritonitis was much more extensive macroseopically than in Case II, being evideneed by serotmlid Huid with fibrin flakes and with green fibrin patches on the intestines. (ase XVI recovered ; Catse II died. Althongli ('alse. Il was a more severo typhoirl, presumably the genemal peritonitis in one case was emused by a virulent infection, and in the other by a non-virulent; yet no lancteriological proof is available in either case.

(iencral septic peritonitis in typhoid arising from threatened intestinal perforation from the necrosel and clanaged areas of peritoneum over the base of ulcers must be accepted as a not very uncommon occurrence. .J. 1. R. (Aairdner ${ }^{22}$ has reported 5 such casses.

'I'o sum up in regard to our first class of cases, namely, 7 with sudelen onset of symptoms, :3 had no general peritonitis evilent to the eye; 1 case laal limiting alloesions around the perforation, with no genceal peritonitis; 2 cases had slight evielence of general peritonitis. These are all of them the most favorable cases for operation, for it must be said of them that operation was actually directed against the infecting cause and not against the resulting general infection. 'The bacteriology was studied in only one of these cases, and in this one a pure culture of the typhoid bacillus was foumd.

It is a fact that the typhoid bacillus has been very rarely found in the peritonitis of typlosid fover, possibly because, throngh delayed operation, cultures

- Annales de l'Inatitut Pasteur, vol, vil, p. 141.

10 Johns Hopkjng Hospital leoports, 1895, vol. 1.

1 Philadolphia Modical Journal, March 3, 19
12 (ilaggow Modica] Journal, vol. xlvil, p. 97. lave not been taken until the typhoid bacillus was overgrown.

It is possible, and probuble, that the others of these carly and secmingly favorable casces for operittion may have hat a genemal virulent infection eithes with typhoid bacilli or streptocoes. It is past conterovorsy that fatal peritoncal infection an have taken place without eausing visible macroseopical signs at operation or autopsy. ()f the 14 cases of entiulual onset or witl early warning symptoms, in every one visible peritonitis was found at operation, and in the majority of eases it was evidently of comparatively long standing.

Comparing the two sets of eases, mamely, the 7 cases with suldent onset and the 14 with endadual onset, we find that in operations done on the aises of sudden perforation within onc to eight, homss after the: first symptoms there was found no genceral peritonitis, but at most a very slight beginning peritonitis; but operation done on those of grradual onset, within one to eight hours after the severe or diagnostic symptoms, fomd extensive general peritonitis - so extensive that in several aises the operator moter that this peritonitis must have oxisted many hours lomger thin the: symptoms would leal one to suppese. Tlie contclusion is plain that in these cases the perforation or the begimning peritomeal jufection took planes at a time: more or less remote from the severe and diagnostic: symptoms.

These 14 catses are cases of operation for gemeral peritonitis which hat existed for a longer or sloorter time - in 1 ase origrinating in a ruptured mesenterie: grland; in another, threatencel perforalion; in 1 from an unknown cause; in 11 from intestimal perforration.

'The prevailing type of peritonitis moted was the seropurulent, with dibrin flakes in the turbid fluid and alloerent fibrin patches on the intestince. Nine casess are noted that had fecess or fluid fecal malker in the intestiual cavity or fluid with a focal orlor. All of these cases were intestimal perforations. Two calses

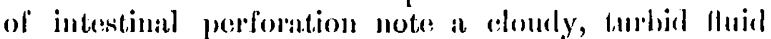
without, fecal odor.

Catse XXI was a case of gencral seropurulant, peritonitis originating in a ruptured mesenterlic: glanel. Cultures showed this to be a pure infection of hacillus typhosus. In ('ase XVII punctate hemorihinges on the intestinal wall are noted, and hrownisl fluid in the peritoneal cavity without oilor.

It is greatly to be regretted that in only 4 of these 14 cases were any bacterial cultures taken, and in certain of these the question arises as to their value, because: of our incomplete knowledge as to how they were taken and because of incomplete reports of the diflepentiation of the valrious bacteria found. Flexner ${ }^{13}$ and Cushing ${ }^{14}$ dwell upon the necessity of making cover-slip preparations as well as plate cultures at the operation from the alorlominal contents in casess of peritonitis, because of the well-known fact that the bacillus coli commmnis overgrows the other orenanisms in the mixed infection. Cushing say's: "Indoubtedly the colon bacilli, being more in evirlenes, were frequently hold responsible for peritoneal infection due: to more virulent but eulturally less ablive oreanisms."

Case XIV is recorded ats showing an infection with colon bacilli and "other varieties of bacteria." Case 
$\mathrm{XX}$ is recorded as having turbid peritoneal fluid with filurin flakes, infeetion with colon bacilli. Case XXI, resulting from a ruptured mesenteric gland, gave a th pure culture of bacillus typhosus. Case $X V$ is reported to have been a specially foul-appearing general peritonitis, in which tho infection was colon bacilli, and " many others not differentiated." 'The 2 eases (Casses V and XXI) in which the peritonitis was found to be due to a pure infection of bacillus typhosus died -1 within twelve homs and 1 on the fourtlı day.

The finding of the bacillus typhosus as the infecting orginism in cuses of peritonitis is exceedingly rane. $\Lambda \mathrm{t}$ most, but i) cisses, including the 2 cases reported in this series, have been publisherl. It may be suspected, reasoning from the evidence furnished by Case $V$ and ('atse XXI, that when it does oceur it is probibly virulent and fatal.

\section{1) $A$ inOSIS.}

The diagnosis of the peritonenil infection within at sufficiently reasonable time from its beginning is a question of the greatest importance to pliysicians and surgeons. So fiur, our study of these calses habs shown us that the diagnosis in 14 cases out of 24 was appinently male later than it might have been, and in 7 casces only once was it made as soon as possible, and that in 3 casses a mistaken diagnosis was made.

It seems fair to suppose thit the majority of cases of intestinal perforation present a slow intestinal infection or a wrinlual onset, or that actual perforation may take place without fulminating symptoms. Cushing hats refereded to what he calls" a "preperforative stake," or a " pre-extratvassation stage," and has attributer the arly complatints of pain to a slight involvement of the serosa and possibly to omental adhesions. II" understands by his "preperforative stage" the "whole period between the first involvement of the serosa, with the formation of customary allhesions at this point, until these allessions (which may for a time constitute the floor of the ulece alter he serosit hats given way) have themselves become broken down, and general peritonitis has taken place." 'I'his comrlition of things is well illustrated in our Case IV, which is a typical case of pre-extravalsation, because of delicate protecting allesions.

It would seem, however, from a study of our cases, that the formation of protecting anlhesions in perforation or threatemed perforation of the ileum is excectingly rane. Monad and Van Verts ${ }^{10}$ state that in theip study of this combition, athessions, however slight, alnost never oceur when the perforation is situated in the ileum, and they further state that peritemeal infection is not always a rapid fulminating allair: lhat it maty oocur slowly from what they aill "propisation" - that is, migration of the baceteria through the necosed and dimmaged intestimal conts - and that this form of infecdion is no less worthy of consideration than the rappiel infection from suiden intestinal rupture and extravasation of intestinial contents.

Intestinal ulecers certainly mat have a preporforattive statge, and by this we me:min il stage of local peritoncal infection and bacterial involvement of the peritoneal cont - whether or not allesions exist. This local infection may cause, general infection withoul. allhesion formation and without perforation.

15 Rovue do chirurgie, 1897, p. 164. pre-extravasation stage properly means a period of time after local peritonitis has taken place in which there is no extravasation of intestinal contents, either because of the neerosed portion of the intestinal wall remaining in place without dropping out, as in Case XVI or in Case II of our series, or because of allhesions, as in Case IV of our series. Local infection of the peritonem causes pain of greater or less severity. 'This pain may not be alpureciated and complained of in very sick and stupid typhoids, but in mild cases may be just as prominent a feature as the pain from the local peritoneal infection of appendicitis before perforation has taken place.

Our series of cases shows that this early pain was alsent in only 7 cises out of 21 ; 5 of these 7 cases were mild cases, in which sudden rupture of the serosia and extravasation took place; 2 cases with equally sudden symptoms had a septic peritonitis already under way, which cuses were so sick and stupid that it was impossible to diagnose the beginning of the general infection.

Fourteen cases, as has been seen, land early warning pain, earlier by a definite number of hours than the severe symptoms, and all these cases were found to be far advancel in general peritonitis at the time of operation. These early symptoms undoubtedly meant beginning peritoneal infection, as is shown by the after development, and the severe symptoms meant general septic peritonitis then existing. Whether these early symptoms meant a necrosed serosa without perforation, or a pin-point perforation protected or not protected by delicate ahesions, it is positive? that genceral septic peritoneal infection started at at time coincialent with these early symptoms and not coincident with these severe ones.

It must be admitted that these 14 cases had andvanced general peritonitis at the time of operation; that they had signs and symptoms anterating the symptoms of peritonitis; that the severe symptoms in the cases of actual perforation differed in no way from the severe symptoms in the cases of general peritonitis from other causes of infeetion; and if this statement is true, then the diagnosis of these cases should have been male before these severe symptoms set in, and, therefore, a decision as to what symptoms are of importance in making a sulticiently early diagnosis of peritoneal infection in these cases is of the utmost necessity.

From a study of these cases and also of the cases reported by Cusling it would seem that complaints of abdominal pain in any typhoid ease, especially if localized, and especially in cases of mild type, should be regarded as serious danger signals. We lave already seen that in our sick and septic cases the condition of the patient may be such that morlerate pain may not be soted, and that therefore a complaint of abdominal pain on the piot of such a sick case may mean an established general peritonitis. (Sec Cases II and VI.)

In the mild cases of typhoid complanint of abrlomi. nal pain should lead to a strong suspicion of beginning peritoneal infection through a preperforative stage, or of a slow peritoneal infection through perforation, with or without temporary adhesions; or of a beginning infection from some other souree than the intestine, as in (ase XXI. 'This plan may vary in severity and locility. It is most frequent in the right iliac region, and is most often associated with 
localized tenderness and spasm. 'To confirn the suspicion of beginning peritoncal infection a leucocytosis, steatily rising, during a few hourly counts, at least, should accompany this pain. Vomiting is rare. The temperature gencrally rises and the pulse also.

It camnot be too strongly empliasized that abdominal pain, especially if locialized, complained of by the patient in the milil or moderately severe typhoids, is not a frequent occurrence unless it means peritoncal infection, localized or general. By pain we do not mean the discomfort or uneasiness accompanying meteorism or distention by gas.

We have male a study, bearing upon this point, of 70 cases of typhoid fever at the Massachusetts General IIospital oceurring in the last two years, and have foume, according to the records, that in the majority of eases of the mild and molerately severe typhoid no genuine abdominal pain whatever was complained of, even in the presence of distention, diarrhea and hemorrhinge. Seventy cases: 20 severe typhoids and 50 mild ; 7 casses died. In only 8 casese was any abdominal pain recorded as a complaint (11.4 per cent.), and 4 of these cases died (1 case with probable certain perforation or peritonitis, 1 of pnemonia, and 2 cases with suspicious symptoms of peritonitis). The other 4 cases had slight and transicnt abdominal pain, and recovered. Aldominal distention of more or less extent was noted in 10 cases, without any pain. Intestinal hemorrhages are noted in 8 aseses, but pain accompanied theses in only 1 case. Diarrhea is recorded as marked in 3 cases, but in only 1 was any pain, and in this slight.

With reference to this simne point the records of the Boston (ity Hospital have been gone over for a year. 1'ain is recorded as complained of in 22 cases out of at total of 160 catses; of these 22 cases 5 are included among those operated on, which leaves 17 cases with pain, or about $10 .(\mathrm{i}$ per e(n) of the total.

Localized muscular spasm and localized tenderness are diagnostic signs of the utmost importince atssociated with pain and leucocytosis.

The question as to whether the site of the perforation or the region of the beginning peritoncal infection materially affects the prognosis hoth of inoperated and operatexl casses is one that needs discossion. 'The fact that the appendix may be the seat of the typhoid perforation was first noled by I)r. R. H. Fits, and the relation of this facet to the progenosis in casess of typhoid perforation was thus stated by him: "The probability of its oceurence (perforative appendicitis) furnishes the hest solution to the prognosis of intestinal perforation in the latter discase; (typhoid fever). Most eases of recovery from symptoms of perforation of the howel in typhoid fever are those in which an attack of appendicitis is most closely simulated, while the fatal cases of perforation of the bowel in typhoid fever are, in the erreat majority of instances, those in which other parts of the lowel than the appendix are the seat of the perforation."

This set of cases does not furnish any case in which the perforation was appendicular. Fit\% found this valricty of perforation in 2 jer cent. of 1 ( $; 7$ casces. In a serjes of cases operated upon - that is, our own set, 24; Cushing's, 8, and Finney's, 3 ; 35 in all Jo) instance occurrs. (Aairdnor's ${ }^{10} 17$ cases included only one of perforcted cppyendix. l'erforation in the appendix ean only have a more favoral,le prognosis

16 Glasgow Modical Journal, 1897, vol, xlvil. because of its occurrence in a fixed portion of the bowel in a remote region where the chances of the peritoneal infection being shut up by protecting and Jife-saving alhesions prevail.

It is certainly misloading to state that most cases of recovery from symptoms of perforation are those in which an attack of appendicitis is closely simulaterl, because - as can be plainly seen from a study of our list of cases - many of them lad heginning symptoms which suggesterl appendicitis, and yet the perforation was in the ileum, and the peritoncal infection became general and fatal. It is imperative that we should not be prevailed upon to wait operation in the hope that the perforation may be in the appendix, considering that the chance of localizing the infection by delay offers more hope to the patient than speedy opreration, because the attack began with right iliac pain and tenderness and muscular spasm. 'The letter teaching is that perforation of the appendix may oecur in typhoid, although rarely; that when it docs oceur the infection maty be localized, as in any cases of perforating appendicitis ; lut the great majority of casess of perforation of the bowel in typhoid fever may simulate an acute appendicitis.

A study of our whole list of 27 cases shows the following: Eleven cases had initial symptoms referred to the right iliae region, with one or more of the symptoms of localized pain, tenderness and spatsm. $\Lambda$ ny one of these cases might have been suspeeted as the: appendicular variety, and delary comselled hecallse of the apparent localization of the signs; but ? cases were perforations of the ileum, followed in all but 1 by genceal infection, and 2 hand no callse for symptoms. In only 3 cases pain and tenderness, etc., wore intial in the left iliac region. (Ono, was a case of ereneral peritonitis from a suppurating gland, and the other 2 cases were very sick eases, in which the peritonitis had heecome extensive and general hefore any symptoms wele noted. In 7 cases the pain and tendermess with rigillity were general. In 1 asc; locality of pain is not given. Therefore, we maty conclucle that the majority of cases of perforation have initial symptoms reforred to the right iliac region; that in a very small pereentage of all sllch casess is the perforation in the appendix ; that general abdeminal pitio and symptoms, or symptoms and signs referred to the left side, point to the existence of a greneral peritonitis, the onset of which lass been granlual and not definitely noted.

\section{LELCOCYTOSIS AS A MIAGNOSTIC SYMIPOM.}

A careful comparative white blood commt at frequent intervals in the presence of aldominal pain in typhoid may furnish the most valuable evidence of beginning peritoneal infection. $\Lambda$ full and complete knowlerlge of lencocytosis in typhoid peritonitis has not been reacherl. 'Thayer, in 1892, dirst showed that in typhoid fever the white bloorl corpuseles are less than normal, or, in other words, that a condition of hypolencocytosis exists, and that the smallest number of lencocytes is usmally foumd at a period of time corresponding to the hejght of the fever. Cilot, in 18:7, reiterated these facts and pointerl out that a low leucocyte comt in typhoid meant freclom from septic complications. ()ur study of 70 typhoid cases at the Massachusetts (icueral IIospital is merely corroborative of the statements of Caloot and 'Thiayer. 'The majority of cases at entrance had a hypolencocytosis 
of about 4,000; the lowest count in an uncomplicated case was 1,800 . Septic complications, as phlebitis and otitis media, caused a leucocytosis. In nearly all the cases, however, only one iwhe count - the one at entrance - is recorderl; and even when this ardy count was high - over 9,000 - no other record is available. Certainly more frequent counts should be male in the future. 'The fact that lencocytosis in typhoid means inflammatory complieations in the majority of instances, and that lencocytosis was present in peritomeal infection, was noted by Cabot (1897) ; and Finney, in his paper on "Typhoid Perforation" (18:17), considered the most important symptoms of perforating typhoid uleer to be " marked increase in the number of white blood corpuseles in association with continued ablominial pain." It does not appear that a full realization of the importance of a falling lencocy te comt or the alsence of lencocytosis in general peritoneal infection is held by a majolity of medieal men. Cabot stated that certain eases of general peritonitis would show no lencocytosis because of their being too sick to react against the infection.

Cushing, in his two papers on this subject, seems to have most carefully studied leucoeytosis as a symptom, and his work strongly suggests that a white blood count, steadily rising from the lirst complaint of ablominal pain (which is confessedly the first warning of local or genceral infection), with eertain fluctuations, reaches a maximum point, and then as steadily falls. 'This he aptly calls the wave of leneocytosis, and raises the question as to whether a falling comit, or an absence of lencocytosis (other symptoms being present) maly not be diagnostic of a well-established aeneral septic peritonitis. IIe considered it rational to suppose that the enormous migration of lencocytes to enter into the seropurulent exudation was a sullicient reason for the falling or cleficient white blood count in general peritonitis. 'This point is a very impertant one to settle, for diagnostic reasons. Cushince's conclusions from a carefiul study of leneocytosis in his cases are here given :

"Il this septic complication, namely, eomplication cansing lencocytosis, is a peritonitis which remains localized, associated possibly with a preperforative stauge of ulceration or with a circumseribed, slowly forming peritonitis after a perforation, it maly be and usually is signalized by an increase of lencocytes in the peripheral eirculation. If, however, a general septic peritonitis follows, the leneocytosis may be transitory and overlooked, as it disappears concomitantly with the great outpouring of leneocytes into the general peritoneal auvity.

"In order that the white blood comnt be of any diagnostic value whatever in the presence of alolominal symptoms it is essential that, for the purpose of comparison, previous counts have been male. An individual count at such a eritical time may be mislealing - in the first place, because a condition of hypoleucocytosis often is a characteristic of the fever, and a count comparatively within normal limits, of from 8,000 to 10,000 , may actually represent a double increase in the number. Secondly, because by a single count the transient wave of lencocytosis may entirely escape notice.

"The flood-tide of this increase is a transient affair, lasting but a few hours in some cases, and may in consequence entirely escape observation, since there ordinarily is a following rapid diminution in number, corresponding to the spread of peritoneal infection. In some instances, when the process for the time remains localized, and in asses in which the preperforative stage exists, the lencocytosis may be of longer duration, the condition being analogous to that associated with acute appendicitis (typhoid or otherwise) before perforative peritonitis has occured. Suppurative complications of typhoid, here or in other situations where they remain localized processes, have ordinarily a persisting leucocy tosis, as is well known."

'These conclusions of Cushing are reinforced by' careful observations, and seem to give the best interpretation of lencocytosis in this class of cases. Whether alosence of lencocytosis in the face of symptoms of peritonitis means well-advaneed general peritonitis in every case has not been proven absolutely. Certainly one sure thing is that a single isolated blood count on the appearance of abdominal symptoms may be of little or no value. In one of Cushing's cases of perforation an hourly blood count showed that the white corpuscles rose in two hours from 4,800 to 10,400 , and in an hour and a half later dropped to 7,000. In another of Cushing's cases of intestinal perforation a drop of 20,000 in three hours after the probable time of perforation is noted. The: appearance of lencocytosis in the presence of abdominal pain may, however, be misleading as a diagnostic symptom of peritoneal infection.

As is well known, the existence of a septic focus, an abscess, or a septic phlobitis olsewhere might furnish cause for the lencocy tosis coincident with alodominal symptoms. (One or more cases have been reported in which the symptoms of peritoneal infection, inchuing lencocytosis, led to an exploratory laparotomy, with negative findings. Cushing has had such a case. Case XXIII in our series is also such a one. Finney has been led to an exploratory laparotomy in which the symptoms suggesting intestinal perforation, including a leucocytosis, were probably due to an iliac thrombophlebitis. This case recovered. It has been found by Cushing that a post-operative lencocytosis occurs after all abdominal operations.

With these facts and theories in mind as representing the latest opinions in regard to lencocytosis as a symptom, reference to our series of cases with a view to find corroboration of these facts furnishes very little of value because of the lack of comparative couints. In almost all of the cises only one bloodcount was makle.

'To take our cases in detail, the leucocyte count is only recorded in 11 cases of the 21 in which perforation or peritonitis was found. In the first set of cases, namely, those without warning symptoms, the leucocy te count is recorded in 4 cases. In Case IV (the case of perforation protected by local adhesions) a lencocytosis of 14,300 was found at all unknown number of hours after the onset of abdominal symptoms. No other count is recorded. In Case $V$ one count at the onset of symptoms showed 6,000 ; 10 other count. Case VI showed a lencocytosis of 13,200 . 'This case was one in which perforation and localized abseess formation took place without any diagnostic eymptoms at a time probably remotely preceding the severe symptoms which demanded operation. Occusional comparative leucocyte counts as a matter of medical routine might have led to the suspicion of a septic complication. Case VII showed a white count of 8,600 at the ouset 
of the symptoms; no other count is recorded. 'The other 3 cases of our first set lave no record of any lencocyte count.

'Taking our second set of cases, namely the 14 in which premonitory symptoms existed, as we have seen, it would have been of the greatest importance diagnostically to have known what the white hlood count had been for several days before the symptoms, and also to have known what the white blood count at efrly intervals after the occurrence of abdominal pain was; yet in only 2 cases was there any leucocyte count taken at this time, and then only one isolated count in each case is recorded.

Case XVI had a white blood count of 6,900 two days before he complained of abdominal pain; at the first complaint of pain a count of 8,000 . 'Then no further leucocyte count was taken for twenty-four hours ; but when severe symptoms (which meant general peritonitis) set in a white count equalled 17,200. Certainly in this caso frequent and comparative blood counts might liave contributed much to our knowledge of a rising and falling count. Case XV, seen after the warning complaint of pain, had a white blood count of 31,000. 'Twenty-four' hours after, when general peritonitis laad set in, the white count laad dropped to 23,000 and 17,000 . (nily these three counts are recoriled.

It is much to be regretted that in this series of cases in which 14 had premonitory symptoms, such slight knowledge in regard to the diagnostic value of the white blood count is available. In Case XIV the blood count at the tine of the first abdominal symptoms showed 10,000 whites, but no other count was taken. Six cases of the 14 record no blood count at the occurrence of either mild or severe symptoms In 6 cases the only blood count was made when severe symptoms appeared. In C'ase XII, a case of extensive peritonitis at operation, the white cells were 3,800. Ii C'ase XIII, also a case of extensive peritonitis, the white cells were 5,400. In Case VIII, also a case of general peritonitis, the white cells were 7,300. In Case II they were 8,000 just before operation.

Here are 4 cases in which an isolated blood count, taken when peritonitis had become general, showed no leucocytosis. Whether a previous leucocytosis had existed, and whether the absence of leucocytosis in the presence of genemal peritonitis is a diagnostic sign, camnot be determined because of the absence of comparative counts in all of these cases.

Case IX haul a leucocytosis of 16,000 after general peritonitis was evident. 'Ten days before the count was 14,000 . No interval counts are recorded.

Case $X$ had a white count of 14,000 with the symptoms of general peritonitis. $\Lambda \mathrm{t}$ entrance to the hospital, ten days before, his white count was 6,500 . No other counts are noted.

It is not possible to establish anything new and valuable in regard to leucocytosis as a symjtom from the study of these cases, because of the lack of sufficient data. 'The one conclusion is that the lencocyte counts in typlooid cases should be sufficiently frequent to be of comparative value ; that any complaint of abdominal pain or the appearance of abdominal symptoms demand frequent counts.

'The question of diagnosis and the relative value of abdominal symptoms and leucocytosis as deciding for operation is illustrated in a negative way in Cases
XXII, XXIII amd XXIV. (ases XXII and XXIII were mild or moderately severe typhoids, practically convalescent in the fourth and sixth weeks of the discase. Case $X X I 1$ had no leucocyte count, and it seems questionable: whether it would be justifiable to operate upon a case with such alolominal symptoms without the corroborative evidence of a leucocyte comit. It has been done, however, in other cases (the case reported by Ilerringrton and Bowlby ${ }^{17}$ ). Case XXIII had practically the same abdominal signs and symptoms as Case XXII, except that there is no record of the temperature at this time, which in Case XXII was rising from a normal curve, and Case XXIII had also a lencocytosis of 12,000 one hour before the operation. While this lencocytosis is not large, the white count had risen from 9,000 twelve hours before the operation. Neither of these 2 cases seems to have been very sick or to have had any great amount of shock. Case XXIV seems to have been a case of typhoid septicemia, in which no certain cause for the abdominal symptoms was found. No leucocyte count and no bacteriological cultures are recorded in this case. Probably he died from typhoid fever, although the presence of a green, necrotic fibrin patch found on a loop of the intestines at the operation leaves room for the thought that the abdominal symptoms and death may have been caused by a virulent peritoneal infection.

\section{RIESU1'T.}

Of the 21 cases in which the local or general peritoneal infection was found at operation 3 cases recovered absolutely - that is, $\mathbf{1 4 . 3}$ per cent. recovered. In Case IV - a case of operation in the pre-extravasation stage - it is noted by Dr. F. S. Watson that the protecting adhesions were very slight and delicate, and that in 1)r. Watson's opinion they would not have long resisted fecal extravasation.

The 2 other cases which completely recovered are Cases XVI and XVII, both cases of general septic peritonitis. 'Together with $A$ bbo's ${ }^{18}$ case they prove that it is not impossible to save cases of gencral peritonitis in typhoid fever. The bacterial infection, however, in both of these cases, as well as in the case of Abbe's, was not determined.

Case I properly should be classed as a recovery from an operation for intestinal perforation in typhoid, for death occurred from intestinal hemorrhage five days after the operation, and the antopsy showed the suture tight and no general peritonitis. If this case can be classed as a recovery, we have four recoveries from operation from acute peritoneal infection in typhoid, or 19 per cent.

Case IX cannot be considered as recovering, but it is a case of deatli caused by giving way of the intestinal sutures put in at the first operation.

Taking our 24 cases of typhoid fever which were operated on, 21 with abdominal infection and 3 with no infection found at operation, we have $(i$ cases of recovery from laparotomy in typhoid fever, or 25 per cent.

Cases XXII and XXIII are noteworthy as slowing that the mere abdominal operation in a slight or moderately severe typhoid is not a very fatal thing whon no peritoneal infection is present. C'ase XXIII was also not a very favorable subject for any opera-

17 Medico-Chirurgloal 'Iransactions, London, vol, $1 \times x \times$, p. 127. 18 Medioal Record, 1895, vol. xlvil, p. 1. 
tion, because of cardiac and renal complications, yet both these cases made uneventful recoveries from the operation. In Case XXII an appendectomy was done for an old chronic process in the appendix. In Case XXIII the operation was simply exploratory. Two of Cushing's reported cases further show that an exploratory laparotomy or a simple appendectomy in a mild or moderate typhoid is usually well borne. We have seen that the 5 cases (Cases I, III, IV, V and VII) were especially favorable eases for operation. 'Three of these died, and they were all cases that could have stood laparotomy just as well as Case XXII or Case XXIII had it not been for the peritoneal infection, the nature of which was undetermined in 2 cases and found to be the bacillus typhosus in 1. 'These 3 fatal favorable cases point to the fact that a fatal peritonitis may set in within from one to two hours after perforation. () these 3 cases Case III died on the third day, Case V on the fourth day and Case VII on the second day.

Of the 14 cases in our second set, in all of which operation found more or less extensive peritonitis, and in regard to which it may be said that the operation was directed against the peritonitis primarily, 12 died; 1 lived eight days and died from secondary extravasation. All the others died within fifty hours after the operation; 2 within six hours, 7 within thirtysix hours, and 1 on the oporating-table.

If we grant, for the sake of argument, that the sick typhoids, 6 in number, might have died from their typhoidal condition complicated by an abdominal operation, even if peritonitis had not been present, we still have 8 mild cases in which the cause of death was probably a peritoneal infection, and not the oporation itself.

Calculating statistics of the operative treatment of general peritonitis from any cause is foolish business. The chances for success in such treatmeut depend on so many factors: the amount and virulence of the infection, the condition and resisting powers of the patient, the differing operative technique of different men, the time of operation, the kind and amount of anesthetic used, etc. In trying to find out why some of these cases lived and some died it would be well to take only the 15 mild cases, throwing out for the time being the 6 soverely sick typhoids as doubtful cases for standing the shock of the abdominal operation, leaving ourselves 15 mild typhoids for consideration. Of these, 5 had perforation without any warning symptoms, and were operated upon very speedily thereafter; 2 recovered, 1 because the operation was done in the promextravasation stage $-a$ rare event; 3 died from peritoneal infection from the intestinal extravasation, although no macroscopical signs - or, at most, slight signs - of general peritonitis were present at the operation. 'Ten of these mild cases had general septic peritonitis at the time of operation; 2 recovered.

When we consider the reasons for the recovery of 2 of these cases and the death of 8 we are brought face to face again with insufficient recorided data. 'The time of operation is recorded in only 3 of the fatial cases : 1 case, thirty minutes; 1 case, thirty-fivo minutes; 1 case, one and a half hours.

The time of operation in the cases that recovered is not noted. 'The kind of bacterial infection in the cases that recovered is unknown. In 1 case that died it was an infection of bacillus typhosus ; in 1 case infection of the colon bacillus and other doubtful bacteria.
Ether was the anesthetic in every case; but the amount given, and the time the patient was kept under it, and the effect on the pulse are in no case recorded.

Cushing has enthusiastically endorsed the use of cocaine anesthesia in exploratory laparotomies in acute abdominal infection in typhoid. He has not, however, proved in his article that the majority of his cases were any better off than the cases operated upon under ether. It is not the feeling of this Committee that operation under cocaine anesthesia is advisable in cases of mild typhoid whose general condition of mind and body is fairly good, because rationally the shock to the mental and physical organism from an abdominal operation, with all its attendant manipulation, to a conscious patient must be greater than the judicious administration of ether. In certain cases of advanced peritonitis in which the patient is sick or nearly moribund, stupid and unintelligent, the use of local anesthesia may be advantageous.

Irrigation of the peritoneal cavity with hotsalt solution or hot sterile water was practised in overy case of general peritonitis but 1, namely, Case XVI. In this case careful wiping ont of the cavity with gauze was done. Drainage with gauze or with tube and gauze was used in overy case but 2, both of which died. It does not appear from available data that these variations in technique affected the result. The surgical opinion is practically unanimous the world over, that the operation for septic peritonitis must include free incisions, careful cleaning of the ablominal cavity by wiping, irrigation and free drainage.

It is impossible to work out by percentages the chances of recovery in cases of intestinal perforation and peritoneal infection in typhoid fever. It is a question of peritoneal infection (kind, amount and virulence), together with the condition and resisting powers of the patient, who has already contended with another disease. It is not the mere fact of operating in these cases that kills them, and it cannot be said that the typhoidal condition forbids an operation. It has been shown that a majority of the cases of perforation and infection are mild typhoids, and it has also been shown that abdominal operation in the absence of infection is not necessarily fatal, but, on the contrary, is well borne. 'The peritoneal infection is the thing that kills in the majority of eases.

A peritonitis from a perforation of the intestine in typhoid may be caused by virulent or non-virulent organisms just as in any other perforation of the bowel. Most of the typhoid porforations operated upon in this series of cases and all cases hitherto published have had a general peritonitis that would kill a majority of the men who had contracted it from other causes than typhoid, namely, perforated appendix or wounds. General peritonitis of the intestinal variety in a strong man, without typhoid fever, is a very fatal affair, and the chances of a recovery from operation in any case cannot be established by statistics except in a general way.

\section{CONCLUSIONS.}

'This series, unfortunately, leaves much to be desired in the way of accurate and carefully reported study of many of the cases in the liglit of the most recent experience; but from the foregroing antysis of the material we can definitely conclude that:

(1) In many very sick typhoids perforation or 
peritoneal infection cannot be diagnosed until the results are already widespread and of fatal extent The chances of a fatal issue from an abdominal operation in such cases are overwhelming.

(2) In mild typhoids of fair general condition an abdominal operation is readily borne, provided no peritoneal infection is present.

(3) A small number of mild typhoids may have sudden perforation with free extravasation. In these the symptoms are fulminant, but localized to a great extent, and in these

(4) Operation must be done at once, for general infection may become past relief in from one to five hours, and walling off of the perforation by protecting adhesions is so rare as not to be counted upon.

(5) In the majority of mild cases, beginning infection (whether from perforation or not) is marked by comparatively slight symptoms - local pain, tenderness, spasm and leucocytosis. The severe following symptoms mean general peritonitis.

(6) 'These warning symptoms demand serious consideration and study, but in many cases are either not rightly understood or not acted upon.

(7) Complaint of abdominal pain in a case of typhoid should always lead to a suspicion of beginning peritoneal infection.

(8) Frequent leucocyte counts are needed in every case of typhoid. In tho presence of abdominal pain an hourly count is necessary.

(9) Pain associated with local tenderness and muscular spasm and a rising white blood count points in most cases to an operation; in all cases to a surgicinl consultation.

(10) In not a few of this series of cases operation was imperative a varying number of hours before it was done.

If it can be appreciated that the severe symptoms more of ten mean general peritonitis, it must be understood that the milder and earlier symptoms are the important ones.

\section{REPOR'T OF CASES.}

Cast I. Seeley, male, age thirty-two years, white. Dr*. Bowditch and 'Thorndike, Boston City Hospital, September, 1899. Sudden perforation. Operation within three hours from first symptoms. No general peritonitis. Death five days after from intestinal hemorrhage. Uneventful until the sudden abdominal symptoms. Mild course. Widal positive. Diazo (?). No complications. No abdominal complaints. Not a sick man. End of sixth week, forty-second day, operation. Ether. Time not known. Incision, right iliac. Irrigation. Gauze drainage. Sudden intense abdominal pain, not localized. Marked slook. Pulsu 150. 'Temperature 102.6 $0^{\circ}$ No leucocyte count recorded. No fall of temperature. No vomiting. Operation three hours after. No general peritonitis. Intestinal contents in abdominal cavity; fluid fecal matter. Perforation in ileum, two feet from cecum. Closed with silk. No cultures. Excellent result for five days. Operation for the perforation successful. Five days after, excessive intestinal hemorrhage causing death. The autopsy slowed that the operation was a success. No general peritonitis. The suture was intact and protected by adberent intestines with slight local peritonitis, from which the colon bacillus and staphylococcus albus were grown. Cultures from rest of abdominal cavity negative.

Care II. Bowler, male, age twenty-five years, negro. Drs. G. B. Shattuck and F. B. Lund. IBoston City Hospital, October, 1899. A case of general septic peritonitis from necrosed patches of peritoneum, without perforation. Symptoms of perforation, however. Moribund at opera- tion. Death. Scvere courso. Widal positive. Diazo (?). Abdominal pain constant. Fourth week, twenty-second day. Operation. Ether. 'l'ime (?). Incision, right iliac. Irrigation and drainage. Very sick case. 'Temperature high. Delirious. Abdominal pain and tympanites at frequent intervals. 'Two intestinal hemorrhages before operation (two days before). Sudden chill, shock, collapse, rising temperature and pulse. Distention. No vomiting. Operated on seven hours after, when in moribund condition. No leucocyte count. No perforation. 'Two necrosed patches in wall of ileum over ulcers. General peritonitis. No cultures made. Gas and serous fluid escaped. Intestines clean and not injected. Several necrotic areas. Necrosed places, inverted with silk. Death in eighteen hours. Cause, peritoneal infection and typhoidal state. Compare this case to Case XVI. 'This case had sudden severe symptoms from peritonitis without perforation. An unfavorable case from all points of view. Peritoneal infection from necrosed patches, probably virulent, whereas in Scappaci's case infection from necrosed patches probably non-purulent, with the abdominal pain and distention marked. Specially associated with hemorrhages. Careful white blood count at frequent intervals might have been suggestive.

CAsi III. McCann, male, age thirty years, white. Dr. F. C. Shattuck and Dr. Warren. Massachusetts General Ilospital, January, 1899. Sudden perforation without warning. Operation within two hours. Death in three days. Mild course. Widal positive. Diazo positive. Bronchitis. No abdominal complaints. Fifth week, thirtieth day, incision, right iliac. Irrigation. Drainage, gauze. Ether. 'T'ime of operation (?). Mild fever complicated by hemorrhagic bronchitis. Intestinal hemorrhage two days before perforation. No warning. Patient comfortable, when sudden sharp pain in right iliac region with great tenderness and muscular spasm. No white count at this time. White count two days before $\mathbf{3 , 8 0 0}$. White count at entrance, ten days earlier, $10,000 .{ }^{\text {No }}$ vomitingr. 'Iemperature subnormal, but began soon to rise. Pulse below 100 . Operation one and $a$ half hours after. Perforation in ileum, site not mentioned. No eral peritonitis. Some free fluid. No bacteriology. Death on third day, in sixty hours, with symptoms of general peritonitis. No autopsy.

Cask IV. Scott, male, age twenty-eight years, white. Drs. Withington and Watson. August and September, 1895. Perforation. Localized peritonitis. Operation in pre-extravasation stage. Recovery. Mild course. No Widal test made. Diazo positive. Rose spots. Eleventh week in a relapse. Operation. Ether. Time (?). Incision right iliac over induration. No irrigation. No drainage. Long course, one or two relapses. No special complications. 'I'wenty-three days before perforation, two or three hemorrhages. No abdominal pain recorded, but some tympanites. Without warning sudden severe pain in right iliac region at 2 A. $M$. Temperature did not fall, but rose. Pain steadily worse. Pulse rapid and weak. Some cyanosis and prostration. Muscle spasm on right side of abdomen. Dulness and indurated feeling to right of umbilicus, "size of liand." No distention. No vomiting. "The symptoms of local pain and rigidity increased while patient's genoral condition improved." Leucocytosis 14,350 . Operation twelve hours after first pain. $A$ loop of ileum adherent to parietal peritoneum around a perforation size of a dime; well.defined area of local peritonitis. Limiting adlesions delicate. "Lvery probability that these adhesions would not have resisted fecal extravasation long and that a general peritonitis would have resulted if case was left to itself." (Watson.) Perforation closed. Recovery uneventful. No cultures.

Cask V. Dolan, female, age twenty-five years, white. Drs. George B. Sliattuck and Lund. Boston City Hospital, November, 1899. Perforation. Beginning general infection with typhoid bacillus. No definite warning symptoms. Death. Mild course. Widal positive. No complications. No abdominal complaints. In second week, twelfth day. Operation. Ether. 'T'ime, thirty min- 
utes. Incision, median. Irrigation. Drainage. Uneventful till twenty-six hours before operation, then hard chill (no other record at this time). Next A.M. (twelve hours after) several chills. 'I'wenty-two hours after first chill and four hours before operation abdominal pain above pubes. 'Tenderness and spasm (more on right). 'Iemperature fell to $98^{\circ}$, but rose at once. No distention. P'ulse 120. No vomiting. Nauser. leucocyte count, recorded as taken when pain complained of, 6,000 . No other count. Perforation eight inches from cecum in ileum. Gas and turbid fluid in general abdominal cavity. General peritonitis not far advanced. Infection, pure typhoid bacillus. Perforation closed with silk, also two thin places enfolded. Death on fourth day, with symptoms of general peritonitis. P'erforated coil of intestine was lying low down in. pelvis. (Note locality of pain above pubes.) Perforation probal,y when pain was tirst noted. Operation reasonably soon. 'Typhoid infection, probably a virulent onc. The general peritonitis was not far advaneed at operation, yet was undeniably a general infection.

Cask VI. Duvlin, male, age twenty-four yen's, white. Drs. F. II. Williams and Munro. Boston City Hospital, November, 1899. l'erforation and local abscess forma. tion, with no diagnostic symptoms, followed by general peritonitis with severe symptoms. Death. Severe course. Widal negative. Rose spots. Iarge spleen. No complications. In fourth week, twenty-sixth day, operation. Ether. 'Time (?). Incision, right iliac. Irrigration. Irainarce. Case stupid and sick. Fever high. No abdominal complaints till special ones. T'wo severe intestinal hemorrhares on day before in A. M. and P. M., accompanied by hard chill and collapse. Very near death at this time. Unconscious twenty-four lours after this. Abdominal pain. 'lenderness, mainly right, iliac. Distention. Riridlity. No vomiting. Lencocytes 13,200 . 'Temperature (?). (Operation twenly-eight hours after lemorrhage. Operation four hours after pain, ete. (ieneral peritonitis with clumbly fluid; pus and feces in left pelvis free. In right iliac region an abscess cavity walled off by fairly stron allhesions, filled with pus, blood and feces; large ragged hole in ilean near eecum. No cultures recorded. Perforation closed. Death in forty-eight hours from general peritonitis. No autopsy. This case was one of perforation and forming of a walled-off abseess with no symptoms complained of by a very stupid, sick man. 'l'ime of extension to a general peritoneal infection doubtful. No cultures from ereneral peritoneal fluid, as well as from local abseess, were taken.

Casis VII. Marchiono, male, age thirty years, white. Drs. Ilenry Jackson and Mtunro. Boston City llospital, July, is98. Perforation. Sudden onset. P'eritoneal infection not known. (Quick operation. Death. Mild cisse. Wilal positive. Diazo ("). No complications. No abduminal complainss. In third week, l.wentieth day, operation. Ether. 'lime, one-lablf hour. Incision, right ilate. Irrigation. Drainage. 'T'en A. s. pain complained of in abdomen, with no special tenderness, nothing local ized. No spasm. Leueocy te count then $8,(610)$ not taken again (?) ; 1.30 l. M. severe pain and shill, collapse. Abdomen everywhere tender and rigid, but especially on right stule. Fall of temperature recorded to $98^{\circ}$, rising soon to 105\%. No vomiting. (Operation eight hours after first pain, five hours after collapse. One perforation in ileum ten inches from eccum. No free hinid. "No extensivo sigus of peritonitis." P'erforation closed. No cultures recorded. Death in forty-eirht homrs without. srmptoms of peritonitis. P'artial autopsy through wouml. Slight mieroseopic signs of genceral jeritonitis, but no bacteriology Canse of death (?). Infection not known. In this caise quick operalion after first symptoms. Begriming peritonitis.

CAss VIII. Schick, male, are sixteen years, white. 1)r. (iannett and 1)r. Mixter. Massachusetts General Ilospital, August, 1897. Case of perforation. Symptoms of peritonitis. l'erforation probably took place some hours before first symptoms. Deatli. Severe course Widal positive. Diazo positive, End of third week, twen- ty-first day, operation. Ether. 'Time (?). Incision, median. Irrigation. Drainage, gauze. Albumin, a trace in urine. Mitral regurgitation. Compensated. White count on entrance 4,000. High temperature and great abdominal distention all the time in the hospital, but no pain till Aurust 20th (tho day before severe symptoms) - that is, twenty hours before operation sharp pain in the left ilias region. No white count. Temperature falling gradually to $99.4^{\circ}$ the following evening. No record of elose watch of case. Next A.M. severe symptoms. Very great pain. Great distention, "board-like abdomen, most tenderness left iliac," bad pulse, anxious facies, no vomiting. White count 7,300. Perforation eight inches from cecum in ileum. Virulent general peritonitis, pus and feces. Intestines covered with filrin. No cultures. "Peritonitis of longer standing than twenty hours." Death in fifty hours. P'eritonitis, spreading from a local area of infection or from perforation which took place without being noted. Simall lencocyte count, possibly due to extensive purulent peritonitis. No comparative counts except one at entrance.

CASE IX. Hanahan, male, are twenty-seven years, white. Drs. Fit\% and Beach. Massachusetts General Hospital, November, 1897. P'erforation. General peritonitis. Operation. "Second perforation" or giving way of sutured area eight days after second operation. Deatl. Mild course. Widal positive. Diazo positive. First of third week, operation. Ether. 'lime, thirty minutes. Incision, median. Irrigation. No drainare. Slight bronchitis. 'Trace of albumin and hyaline and granular casts in the urine. Nothing pointing to the aldomen save a littlo distention. No intestinal hemorrhages till after the first operation. December bith, distention and tenderness to the right of the umbilicus. 'Temperature rising, pulse stealy, no white count then. Lemooytosis at entrance, November 27th, 14,100; November 29 th, 14,200; December 8 th, 16,000 . December 7 th, tenderness increas ing and temperature rising. No white count. Deecember 8th, gradually falling lemperature and great increase in tenderness and distention of aldomen. Liver dulness obliterated. White count 16,000. (ieneral tenderness, pulse 130 , temperature $104^{\circ}$. No vomiting. No complaint of pain. Operation next day (1)ecember 9th), about sixty hours after lirst warnings and after twenty-four hours after symptoms of general peritonitis. The infection was a slowly spreading one; the severe symptoms on December 8th were probably due to the general peritonitis. The condition on l)ecember 6 th and 7 th strongly sugrests a proextravasation stage, but comparative blood counts are not recorded. Operation would certainly would have been justified by these syinptoms of peritonitis fully fifteen hours before it was actually performed. Perforation one-eighth inch in diameter, one inch from cecum in ileum (Beach). Closed. Foul gas and fecal fluid in belly. Yellow fibrin on intestines. No bacteriologr. Did well after operation sive for the continuation of typhoid lemperature, averaging $102^{\circ}$, and three or four moderate intestinal hemorrhages. Some distention. Eight days after first operation pain all over belly, followed in three hours by collapse. Second operation found large necrotic area and ragged hole in the cecum which was, for a great space around ulcer, soft and ganerenous - "shows patches of necrosis." l'eritoneal cavity contained much dark fluid, feces and blood. Died five hours after. Autopsy: Much foul fluid in the peritoneal cavity. Many ulcers in last three feet of ileum and in ascenciing colon. In cecum large necrotic areas, two small perforations, and two ragged large openings. In ileum no ulcer throngl to peritoneal coat, and no sutures found. Although this case has been considered a case of second perforation after recovery from the first perforation, the facts do not permit this view of it. 'Tlie first perforation was said to be one inch from the secum; the second operation and the autopsy found areat necrotic softening and ragged hoies in the cecum, and the autopsy found no ulcers in the ileum which were through to the peritoneal coat, and no trace of the silk sutures. The localities are practically coincilent. It seems just to add that the case did well after the first operation until the 
extensive necrotic changes in the cecum involving the sutured area caused giving way of sutures and second extravasation. Certainly eight days is too short a time in which a sutured ulcer could heal and vanish, and the silk sutures would not have disappeared.

$\mathrm{C}_{\text {ass }} \mathrm{X}$. Hoyt, male, age nineteen years, white. Drs. F. C. Shattuck and C. B. Porter. Massachusetts General Hospital, October, 1896. Perforation. General peritonitis. No full study of early and warning symptoms recorded. Death. Mild course. No Widal test made. Diazo. No complications. No abdominal complaints. 'Thirteenth day, last of second week, operation. Ether. 'lime (?). Incision, median. No irrigation. Wiping. Gauze drains. No hemorrhages. Uneventful till October 2(ith. Pain in abdomen growing steadily worse. No collapse, no fall in temperature then. Pain steadily increasing. Legs drawn up. No records of any examination for spitsm, ete., but records of morphine given. No white count. Eight hours after pain tirst noted symptoms of general peritonitis. P'ulse 112 , sweating, temperature down somewhat, pinched face, belly rigid, tenderness general. Liver dulness not obscured. No vomiting. White count 14,700. Operation eleven hours after first symptoms. Perforation in ileum "near cecum." This is called in record " a sloughing area from which gas was escaping, but no fecal matter." General peritonitis, seroturbid fluid of fecal odor. No bacteriology. Perforation infolded with two rows of sutures. Death in thirty-six hours after great distention with obstinate vomiting. 'The autopsy raises a specolation as to the cause of death - whether due to obstruction from too much infolding of intestines by the two rows of sutures. The lumen of intestine at the point of suture admitted the little finger-tip, but was obstructed by a hard, impacted mass of feces. Whites at entrance 6500. Hight hours after first pain 14,700.

Casr XI. Bresnalan, female, age forty years, white. 1)r. C. A. Porter and Dr. 'Thompson. St. Elizabeth's Hospital, August, 1899. Perforation. Definite carly symptoms, which were not considered important. Operation six hours after severe symptoms. Death. Mild type and course. No Widal test made. No diazo. Rose spots, etc. No complications. No abdominal complaints. In third week, operation. Ether. 'Thirty-five minutes. Incision, rigltt. No second incision. Irrigation. Drained with gauze. Uneventful case. No intestinal hemorrhages. 'Twenty hours before operation, pain in abdomen with some tenderness. No white count. No examination through the day. Six and one-half hours before operation pain severe, pulse 135. 'Three and onc-half liours before operation - that, is, sixteen and one-half hours after first complaint of pain - symptoms of collapses (general peritonitis). 'Temperature $106^{\circ}$. Muscle spasm and tenderness in riglat iliac region. No vomiting. Jeucocytes 8,000 . One perforation six inches from cecum in ileum. V-shaped resection, silk sutures, one thin place inverted. General peritonitis. Free fluid of fecal odor. Injected intestines, with fibrin flakes. No cultures taken. Infection unknown. Death thirty-seven loours after. Partial antopsy through wound. Existence of other perforations unknown. Cause of death, peritoneal infection. Beginning infection probably when first pain, twenty hours before operstion. No importance attached to arly symptoms. Severe symptoms due to general peritoneal infection.

CAse XII. MoDonald, femule, age twenty-six years, white. Drs. Buckingham and Munro. Boston City Hospital, September, 1899. Case of perforation with excessive general peritonitis. perforation and peritonitis much earlier than diagnosed. No symptoms save of general peritonitis. Deatl. Severe course. Widal positive. Diazo (?). No complications. No abdominal complaint. First of tifth week, thirtieth day, operation. Wther. 'lime of operation (?). Incision (?). Eutered the Boston City Hospital in the fourth week. 'Two intestinal hemorrbages five days before "perforution." After these very sick, stipid. Pulse and temperature high. Some abdominal distention. No abdominal pain until the morning of september 18 th, then puin and tenderness, requiring mor- phine. Four hours after this great distention, general tenderness, chill, collapse, poor pulse, temperature fell to normal, but began at once to rise. No vomiting. Lencocytes 3,800 (note, general peritonitis with excess of fluid) No other count recorded, and no time of this given. Operation six hours after pain, two after collapsc. Case "moribund" at operation. Perforation site not recorded. “ Excessive goneral peritonitis, evidently of longr standing; appearance of intestines and abdominal cavity showed general peritonitis of much longer standing than six hours" (Munro). No bacteriology. Death on operating table. No post-mortem. "This case was "stupid" and sick, and illustrates that perforation and general peritonitis may le gradual, and in a sick and stupid patient unnoticed until extreme septic infection.

Cast XIII. Starnar, male, are twenty-five years, white. Drs. Gannett and C. B. Porter. Massachusetts (iencral Hospital, October, 1899. Perforation eralual, General peritonitis of long duration. No very definite diagnostic symptoms. Death in two hours. Mild case. Widal positive. Diazo positive. No complications. First of fourth week or end of third, operation. Lither. 'Time, one and one-half hours. Incision, median. Irrigation. No drainage. In the hospital ton days before operation. Al. domen distended most of the time, but no pain. Patient dull and stupid. 'Temperature high, pulse rood. Four' A. M. intense pain, abdominal distention. No examination. Eight A. M., Sertember 13th, sudden vomiting. No pain complained of, but abdomen much distended and kneess drawn up, fuce anxious, general rigidity, abrlominal and general tenderness. No fall of temperature recorded. White count, 8.30 A. M., 5,400 ; 10 A.M., 4,400; 2 1. M., 6,300. (Operation I welve hours after first pain. General peritonitis, eloudy fluid, gas in large amounts. Intestines inuch injected, distended, covered with fibrin. Perforation just above ileocecal valve in ileum, "pin-head," closed. No culture. "Condition on leaving table very bad." Death in two hours. No autopsy.

Case XIV. McKenna, male, age thirty-eight years, white. Drs. (ieorge B. Slatiuck and F. B. Jund. Bos ton City Hospital, December, 18!)8. Perforation. Cieneral peritonitis. Definite warning symptoms. Deatls. Severe conrse. Widal positive. Dia\%o (?). No complications. No abdominal complaints. Find of third week, twenty-first day. Ether. Time (?). First incision in right iliate, second in left. Irrigation. Drainage, gauze and tubes. Seven P. M. of the day before operation general abdominal pain, also pain in rectum and bladder. General abdominal tenderness and rigidity. No cliange in pulse and temperature. Irucocyte count 10,000 . Query as to why this was not repeated. No record of any observation of case till next day. The next morning ( 1 welve hours after warn. ing) symptoms of peritonitis recorded, namely, distention, anxious facies, vomiting, no fall of temperature, pulse rising to 120 . Operation fifteen hours after first symptom. Perforation in ileum one foot from cecum. Closed. Seropurulent general peritonitis, pus and feces, fibrin. Infection, colon bacillus and other bacteria. Death in forty-lwo hours. Antopsy showed genural peritonitis. No other perforations. Beginning of infection when first pain, fif. teen hours before operation. Definite warning. No record of case for twelve hours. Lencocyte count day before, when sugrgestive symptoms appeared.

Case XV. Mahr, male, age thirty years, white. Drs. Bowditch and Watson. Boston City Hospital, February, 1898. Perforations. General peritonitis. Early sy'mptoms definite. Operation delayed forty-eight hours. Deatl. Mild course. No Widal. No diazo. Post-mortem proof. End of third week, operation. Ether. 'Time ('). Incision, median, and two counter incisions in flanks. Irrigation. Drainage tubes and gauze. No special complications. 'Temperature normal for two days. No abdominal complaints till last. September 15th, A. M., vomited and complained of sudden pain, first in eplignstrinm, thon all over abdomen and shooting into testicle. 'Tenderness in abdomen general but most marked in right lower region and in epigastrium. "Shock not marked." 'Temperature 
rose from normal to $102^{\circ}$. Pulse 150 . In a few hours rigidity of abdomen and tympanites. Leucocytes on September 15th, 31,550; next day, 17,000 to 23,000 (September 16th). In spite of these marked warning symptoms no operation for forty-eight hours. 'Then symptoms of fatal peritonitis, case nearly moribund, temperature subnormal, cold extremities, marked prostration, cyanosis, marked distention and rigidity. Operation found perforation in ileum near cecum, size of "split pea." Found general peritonitis, pus, fecal fluid, dirty-gray lymph, coils alherent, pelvis full of turbid fluid, perforated coil fastened in abdominal wound. Infection, colon bacillus and great variety of other bacteria (?). Death in six hours. Autopsy: Numerous typhoid uleers in lower ileum. A second perforation (pin-point) close to valve. General peritonitis. A repeated white count in this might have contributed much to the knowledge of a falling count in peritonitis.

CAsw XVI. Scappacci, male, age nineteen years, white. Dr's. Cutler and Elliot. Massachusetts General Hospital, June, 1899. General peritoneal infection from a necrosed and gangrenous patels over an ulcer. 'l'hreatened perforation. Definite warning symptoms of infection. Recovered. Mild course. Widal positive. No complications. No abdominal complaints. Last of second week, operation. Ether. 'Time ('). Incision, median. No irrigation, but wiping. Gauze drainage. Uneventful till June 4 th, then pain in lower abdomen with general tenderness. Lencocytes June $2 d, 6,100$; June $4 \mathrm{th}, 8,000$. No complaints or examination recorded for June 5 th. June 6 th, severe pain, abdomen tender and rigid, but more on right side; tympany, anxious facies, pulse 120 , fall of temperature. Leucocytes 12,200. No vomiting. Operation two days after first abdominal pain. Four hours after, symptoms severe. Four feet from cecum a necrotic patch of peritoneum, the base of intestinal ulcer. General peritonitis, seroturbid, purulent lluid and fibrin flakes. Intestines injected, with green fibrin patches occasional. No cultures. Patch inverted. Recovery after relapse of typhoid. Infection not determined. $\Lambda$ case of perineal infection from ulcer not yet perforated. Symptoms of perforation all present. Infection probably non-virulent (?). Compare Case XXI.

Casi XVII. Bloom, male, age forty-five years, white. Dr. Brooks. Massacliusetts General Hospital, September, 1898. Extensive general peritonitis from perforation in walking typhoid. Infection not determined. Recovery. Widal positive. Ambulatory case. In second week, operation. Esther. 'lime (?). Incision, right iliac. Irrigation. Drainage, gauze. Case of typhoid as shown by Widal and by finding of typical nlcer indurations in ileum. Had been sick for a week or ten days, with pains in abdomen. $U_{p}$ and about out of bed most of time (walking typhoid). Brought to accident-room 3 A. M. in bad condition. Femperature $103.4^{\circ}$, julse 134 , respiration 60 . Histury of pain in region of appendix, severe for two days, with nausea. (Operation found brown, purulent fluid in general peritoneal eavity, with no odor; portions of small intestine covered with hemorrhagic spots, "size head of tack." Perforation found one foot from cecum. "Indurated aren, size of quarter, in centre of which pin-point opening." 'The appendix removed, incidentally, for old thickening. No active process in it. Perforation took place two days at least (?) before entrance. No white count. Recovered. No return of typhoid state, though Widal positive after operntion. Discharged, well, in six weeks. No bacteriology.

Casn XVIII. McCarron, male, age thirty years, white. Drs. Bowditeh and Thorndike. Boston City Ilospital, Octoler, 1899. Perforation. Beginning general peritonitis. Operation eicrht hours after first symptoms. Death. Mild course. Widal positive. Jiazo (?). No abdominal complaints. In the fifth week, thirty-third day, operation. Sther. 'I'ime (?). Incision, right iliac. Irrigation. Drainage, tubes and gauze. Cardiac murmur, systolic, not affecting compensation. No other complications. Early warning symptoms: 2 A. M., sudden, sharp pain in right iliac region. No fall of temperature, grood pulse. Vomited. No blood count in this case. Seven A.M. (five hours after) severe symptoms. General severe abdominal pains and rigidity, especially right iliac. Pulse 120 . Vomiting. Operation eight hours after first pain. Operation three liours after severe symptoms. Perforation in ileum three feet from cecum. Perforation closed with silk. Strawcolored fluid and fecal matter in ablominal cavity. Intestines injected and fibrin flaked - that is, beginning general peritonitis. No cultures recorded. Death eighteen hours after. No autopsy. 'This case perforated eight hours before operation, when pain noted. If the case had been carefully watched with hourly blood counts between the hours of 2 A. M. and 7 A. M. operation possibly could have been decided on three or four hours sooner. Severe symptoms at $7 \mathrm{~A}$. M. due to general spreading infection.

CAsk XIX. Ellam, female, age twenty-one years, white. Drs. 'Townsend and Burrell. Children's Ilospital, October, 1899. General peritonitis. No perforation found. Symptoms of perforation or of peritonitis. Warning pain sudden and not reported. Death. Moderately severe. Widal positive. No complientions. No abdominal complaints. Fifth week, thirtieth day, incision, right iliac region. Irrigation. Ganze and tube drainage. Intestinal hemorrhages daily from three days preceding severe symptoms. No abdominal pain with them. Sudien sharp abdominal pain in the middle of the night; no examination. At 9 . $\mathrm{M}$. (eight hours after) severe pain, abdominal tenderness and resistance, marked in right upper yuadrant, slight distention. No lencocyte count recorded. No vomiting. Pulse 130. No fall in temperature noted, but rise to $104^{\circ}$ at 9 A. M. May lave fallen in the night. Operation eleven and one-half hours after pain. General peritonitis. Injected fibrin flaked intestines. No perforation found. "'I'lin place," but not necrosed; turned in. "Condition forbade search" for cause of peritonitis. No bacteriology. l)eath in twelve hours. No antopsy. This case could have been operated sooner. Severe symptoms came sudsuddenly and were not reported for seven or eight hours.

Casi XX. Buckley, male, age thirty-four years, white. Drs. Jackson and Munro. Boston City llospital, September, 1899. Signs suggestive of perforation in third week. Very sick after this. Perforations in nintl weck. General peritonitis. Warly warning symptoms, Death. Severe course. No Widal. No diazo. Rose spots. Cardiac enlargement. Systolic murmur. In nintl week, fift,y-nintl day, operation. lither. 'Time (?). 'I'wo incisions, first median; second right flank. Irrigation. Drainage, gauze and tube. In the third week, while pulse and temperature were high, sudden fall of temperature. Collapse. Distended abdomen. Operation advised and refused. Jeucocyte count then 6,800 . No other count recorded. From this attack very sick until ninth week. Abdomen distended. Pulse and temperature high. One small intestinal hemorrhage in fourth week. 'I'wenty-four hours before operation abdominal pain, especially on left side. Pulse and temperature rising still higher. Twelve to fifteen hours after pain general and severe. Fomiting. Temperature subnormal. "Two perforations in ileum three inches apart (where?). Also in ileum (site?). "Recent sear, possibly healed perforation of third week." Perforntions closed. General peritonitis, elondy fluid with fibrin flakes. Infection, colon bacillus. Deith ten days after. No autopsy. A frequent leucocyte count would have been very valuable.

CAsis XXI. Powell, male, age twent,y-siven years, white. Drs. Ames and Munro. Boston City Ilospital, September, 1899. No perforation. General peritonitis from ruptured mesenteric glands. Symptoms of perforntion exactly simulated. Infection, pure typhoid bacillus. Death. Mild course. Widal positive. Dinzo (?). No complications. No abdominal complaints. Last of third week, twenty-first day, operation. Ether. 'Time (?). Incision, median. Irrigation. Drainage. Pain, abdominal, more on left side at 11 P. M. 'This required morphine. No further record till $7.30 \mathrm{~A}$. M. (eight and one-half hours later), when collapse, anxious facies, tympanites, general 
abdominal tenderness, and rigidity. Temperature rising. ('Temperature had been normal for twenty-four bours.) No vomiting. No lencocyte count. Operation twelve hours after pain. No perforations. 'Two suspicions thin places of inflamed peritoneum over ulcers. Seropurulent general peritonitis. Infection, pure typhoid hacillus. Death in twelve hours. Autopsy: No perforations. General peritonitis from two softened and ruptured mesenteric glands. 'This case strongly suggests the idea that syinp. toms of general peritonitis are identical with the "sup)posed symptoms" of perforation, ind sugrests the virulence of bacillus typhosus in peritonitis.

CAsk XX11. Sawyer, female, age sixteen years, white. Drs. (x. B. Shattuck and Watson. Boston City Hospital, December, 1897. No perforation. Nothing to account for symptoms of infection. Leucocyte count not taken. Recovered. Mild conrse. Widal positive. Diazo (?). No complications. No abdominal complaints. In sixtl week, thirty-sixth day, operation. Ether. 'I'ime (?). Incision, right iliac. No irrigation. No drainage. Uneventful case. 'Temperature falling steadily. At no time especially sick. The afternoon before operation, severe abdominal pain and tenderness in right iliac. 'Temperature rising to $104^{\circ}$. Pain local in "lower abdomen," gradually increasing, not sudden. Next morning pain and tenderness general, but more on right side. 'Temperature $102^{\circ}$. pulse 128. No vomiting. Abdominal muscles rigid. No distention. No leucocyte count. "Absence of marked shock." Opreration seventeen to eighteen hours after first symploms. No perforations. No peritonitis. $\Lambda_{\text {ppendix }}$ not actively inflamed, but bound by old albesions; removed. Recovery uneventful, Important case from diagnostic side. Pain, tenderness, rigillity, rise in temperature and pulse. No great shock. No vomiting. The leucoryte count is all important, but is not recorded.

Casn XXIII. Eagles, female, age twenty years, white. Drs. Vickery and Mixter. Massachusetts General Hospital, August, 1898. No perforation found at operation. No cause for symptoms of perforation, which were definite. Recovered. Moderately severe. Widal positive. Complications, cardiac and renal. Abdominal complaints frequent. Fourth week, operation. Lither. 'Time (?). Incision. No irrigation. No drainage. Moderately severe case. Complicated by mitral regurgitation, with poor compensation and by acute renal congestion. Both cardiac and renal complications improved in hospital. Frequent complaints of moderate abdominal pain, which was due to retention of urine and relieved by catheter. Probably cystitis. Temperature lower and sitting up in bed in fourth week, when pain in abdomen complained of ; white count at this time 9,200. Isencocyte count at entrance 4,200; twelve hours before operation 9,200, when pain first com plained of ; one hour before operation 12,000. 'T'welve hours before operation, pain, abdominal tenderness and spasm, mainly on the right side; slight distention; pulse 118. Temperature (?) No vomiting. Operation twentyfour hours ufter pain first noted. Nothing found. Recovery. Symptoms of gradual perforation, including some leucocytosis. No marked shock recorded. Query as to how to account for leucocyte count. Compare this case with Sawyer, Case XXII. Same symptoms, but in Sawyer's case no leucocyte count. 'The comparative value of lencocy to count in this case is questionable.

CAse XXIV. Seile, male, age twenty-seven years, white. Dr. Balch. Massachusetts General Hospital, September, 1897. Symptoms of peritonitis of gradual onset. Operation found necrosed patch, but no microscopic general peritonitis. No leucocyte count. No cultures. Ieath. Mild course. Widal positive. No complications. Fifth week, operation. Ether. Time (?). Incision, median. Irrigation. No drainage. Slight intestinal hemorrhages at intervals for three weeks before operation. 'Ien days before, abdominal distention, but no pain or rigidity. Temperature rising. Distention only transient. none two days before operation. September 25tl, at noon, pulse 140 ; some sweating in the afternoon. Pain below and to left of umbilicus. Abdomen distended (spasm, vomiting and white count not recorded). ('lemperature not recorled.) September 26th, picture of peritonitis, anxious face, pain, restlessness. Ijiver dulness obliterated. Operation twenty-four hours after first symptoms. No perforation, one Peyer's pateh, one and one-half feet from cecum, threatening perforation, with fibrin area on intestine, "green, necrotic area," this inverted. No extravasation in peritoneal cavity. No hacteriology. Death in ten hours. Autopsy showed no general peritonitis. Only local necrotic patch. Death from typhoid.

CAsr A. Eladed, male, age fifteen years, white. Drs. Bowditch and Munro. 1899. Case of general peritonitis. No perforations. (iall-bladiler infected with typhoid bacilli. Cause of peritonitis unknown. Sick case. Widal negative. Dia\%o negative. Large spleen. Sick for four weeks. Came into hospital with general peritonitis. "Noarly moribund at entrance" (Bowditch). Delirious; distended belly; distended, rigid muscles; ten perature $104^{\circ}$; pulse 120 . Idencocytes 5.200 (note, purulent peritonitis of long standing). No symptoms of perforation. At operation for general peritonitis no perforations found. Gall-bladder opened, but no evidence of origin of peritonitis. Cultures of free peritoneal fluid, stapliylococcus albus. Cultures from gall-bladder, bacillus typhosus. Lixploration only half satisfactory (Munro). No anatomical evidence of typhoid found. Death in twenty-four hours. No antopsy. No conclusive proof that this was a case of general peritonitis during typhoid. Moribund case of general peritonitis, canse of which doubtful. Slsonld not be counted witl other cases.

Case 13. Collins, male, age twenty-five years, white. Drs. Jackson and Gavin. Boston City Hospital, Srptember, 1895. Case of general peritonitis. No evidence of typhoill fever. No Widal. No rose spots. No spleen. Case of no value. This case hat general peritonitis, was operated on and died. No reason to call it typhoid. No post-mortem. Lencocytes 32,000 before operation.

Casis C. James, male, age (?). Jr. Munro. Boston City Hospital, 1895. Case of general peritonitis. No evidence of typhoid or of perforation. Case of no value. Case entered the Boston City Hospital with general peritonitis. ()perated on and died. No cause for peritonitis found. No autopsy.

\section{SWPARATION OF 'TIE EPIPHYSIS OF 'IIIE OIJERANON. \\ BY r. . . соT'TON, M.b., BOSTON.}

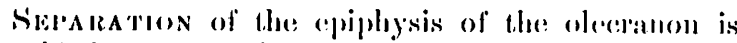

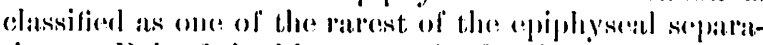
tions. Poland, in his rocent book, wives no instance of this separation save as a complication of other injuries of the ellow, muless one anecepts a doulotiul cass: by Bryatut, and a case of llamiltou's whore loe produced the injury by foreed flexion in attempting to rerluce an old dislocation of the (nllow. Nor hat the writer, in a short search of the literature, found any case recorded where this separation occurred without other injury.

There is experimental evidence enough (1'oland, Gueretin and Salmon) to show the possibility and (asse of separating this epplopysis, but curiously enomgh, all the experimenters sexm to have userl forced hyperextension to produce it. Muscular action in resisting flexion, the apparent cause in the following cases, caunot, of course, readily be innitated on the caulatver.

Both the casess here reported came umler the care of the writer while he was acting ont-patticnt surgeon to the (ity Hospital.

The first cases was in a naval apporentice, a liul of sixteen years. He gave a history of having had a fall on the hand without any blow on the clbow. 